\title{
Troels Schultz Larsen og Karl Löfgren \\ Empiriske studier af samarbejdsdrevet innovation i den offentlige sektor - TRYK Politi som case
}

Samarbejdsdrevet innovation i den offentlige sektor er blevet et etableret begreb i en dansk kontekst. Imidlertid er der ikke etableret en klar forståelse af, hvorledes samarbejdsdrevet innovation defineres eller studeres. Med det formål at vurdere styrkerne og udfordringerne bringes Sørensen og Torfings analytiske model til studiet af samarbejdsdrevet innovation i den offentlige sektor i spil i en konkret case-analyse. Casen er TRYK Politi - et pilotprojekt i samarbejde mellem Rigspolitiet og Nordsjællands Politi, som havde til formål at inddrage borgerne i det kriminalpræventive arbejde via mobilteknologi. Analysen viser, at Sørensen og Torfings model er en både interessant og relevant model, der er anvendelig i konkrete empiriske studier. Analysen viser også, at der er visse udfordringer for modellen, og at denne kunne styrkes yderligere gennem et teoretisk udviklingsarbejde - herunder af selve innovationsbegrebet.

Formålet med denne artikel er at bidrage til den akademiske debat om offentlig innovation generelt samt at vurdere fordele og udfordringer ved en nyudviklet analysemodel for studiet af samarbejdsdrevet innovation i den offentlige sektor. Innovation og samarbejdsdrevet innovation i den offentlige sektor er efterhånden blevet etablerede begreber i en dansk politisk og samfundsvidenskabelig kontekst (Bason, 2007; Bhatti et al., 2011; Fuglsang og Pedersen, 2011; Jensen et al., 2008; Kristensen og Voxted, 2011; Sørensen og Torfing, 2011a). Imidlertid er der endnu ikke etableret en klar forståelse af, hvorledes innovation defineres, eller hvorledes innovation i den offentlige sektor studeres (Bommert, 2010; Vigoda-Gadot et al., 2008; Mulgan og Albury, 2003). Et af de få forsøg, der findes på at formulere en systematisk analysemodel for innovation i den offentlige sektor, er Sørensen og Torfing (2011a; 2011b). Til trods for deres ambition om at skabe akademisk debat og bibringe empiriske studier har ingen imidlertid taget handsken op endnu. Vi vil i den anledning afprøve, hvorledes analysemodellen fungerer i en empirisk kontekst med udgangspunkt $i$ et casestudie.

Fundamentet for artiklen er et empirisk studie af innovationsprocessen omkring pilotprojektet TRYK Politi ved Nordsjællands Politi (NSjP) udarbejdet i regi af forskningsprojektet CLIPS (Collaborative Innovation in the Public 
Sector). I forhold til samarbejdsdrevet innovation er politiet en interessant case, fordi det er en af de mest hierarkiske - og i visse henseender mest lukkede organisationer i den offentlige sektor med en meget stærk fagprofessionel identitet og en organisationskultur, der i udgangspunktet kan vanskeliggøre innovation, inddragelse af borgere og samarbejde med forskellige eksterne parter. Endvidere er TRYK Politi et eksempel på en multilevel case, hvor samarbejdsaspektet ikke bare relaterer sig horisontalt til samarbejdet mellem forskellige "eksterne" aktører (politiet, private firmaer, borgerne), men i særdeleshed vertikalt til en række "interne", men dog relativt autonome aktører inden for politiet på forskellige niveauer. Der er således intet i selve begrebet "samarbejde", som tilsiger, at der skalvære tale om fx offentligt-privat samarbejde, før der kan tales om samarbejdsdrevet innovation. Det centrale ved samarbejdsaspektet i forhold til samarbejdsdrevet innovation ligger $\mathrm{i}$, at der er tale om et bredt sammensat netværk af aktører, hvilket er tilfældet for TRYK Politi.

Selve artiklen er struktureret med udgangspunkt i Sørensen og Torfings analysemodel, og artiklen falder i syv korte afsnit fordelt på en teoretisk del og en mere case-orienteret del. Indledningsvis skitseres Sørensen og Torfings definition af innovationsbegrebet og deres analytiske model. Denne tager afsæt $i$ en forståelse af, at alle innovationsprocesser er indlejrede i en institutionel arena, der er påvirket af en række faktorer. Disse faktorer udgøres af de forskellige eksogene forudsætninger, som påvirker den institutionelle arena, de ledelsesmæssige forudsætninger for og opbakning til innovation, de forskellige barrierer og drivkræfter for innovation, der gør sig gældende, samt de processuelle aspekter, der knytter disse faktorer sammen. Denne diskussion leder over i en introduktion til vores analysestrategi og vores datamateriale. Herefter følger artiklens mere case-orienterede del, der er struktureret efter analysemodellens fire ovennævnte faktorer. Artiklen afrundes med en diskussion af, hvad erfaringerne og implikationerne fra analysen af TRYK Politi kan fortælle os om styrkerne og udfordringerne ved Sørensen og Torfings analysemodel.

\section{Samarbejdsdrevet innovation i den offentlige sektor: definitioner og analyse model}

Sørensen og Torfings model for samarbejdsdrevet innovation i den offentlige sektor udgår fra en definition af innovationsbegrebet, hvor: "Innovation referer til en mere eller mindre intenderet og proaktiv proces, som udvikler, implementerer og spreder nye og kreative ideer, der skaber en kvalitativ forandring i en given kontekst" (Sørensen og Torfing, 2011a: 29). Det er vigtigt allerede her at understrege, at denne definition er en kontekstuel og processuel definition. Hermed gives ikke en apriorisk eller eksplicit definition af, hvad innovation er. 
Derimod henleder definitionen opmærksomheden på en række til dels overlappende faktorer, der er konstituerende for, hvorvidt konkrete processer kan defineres som innovative eller ej. Dette fremgår også af den specifikke kobling, som Sørensen og Torfing skitserer mellem deres definition af begrebet og deres diskussion af, hvad der konstituerer en innovationsproces. Der bliver hermed tale om et processuelt innovationsbegreb i fire led, der analytisk kan skildres som a) udvikling, b) udvælgelse, c) implementering og d) spredning. Det er imidlertid vigtigt at holde sig for øje, at disse faser ikke nødvendigvis skal forstås som kontinuerlige eller kausalt sammenhængende (Sørensen og Torfing, 2011b: 851).

At der er tale om en processuel definition fremgår også af de fem implikationer, Sørensen og Torfing drager af deres definition af begrebet; for det første fremhæver definitionen, at innovation altid er kontekstuel. Det vil sige, at en innovation ikke behøver at være unik men blot ny i den givne kontekst. Dette perspektiv indebærer også en forståelse af, at overførslen af en ide fra en kontekst til en anden i reglen altid medfører en oversættelse og tilpasning til den lokale kontekst. For det andet er innovation altid udtryk for en intenderet forandring. Ikke i den forstand at resultatet skal kunne forudsiges, men forstået således, at forandringen skal være resultatet af en bevidst afsøgning efter nye ideer, løsninger eller modeller mv. For det tredje er det at få en ide ikke det samme som en innovation. At få en ny ide er en vigtig forudsætning for en innovationsproces, men det kræver, at ideerne implementeres og spredes, før at der er tale om en reel innovation. For det fjerde forudsætter den ovenstående definition, at der skabes en kvalitativ forandring, eller med andre ord at der er effekter af implementeringen af den nye eller kreative ide, hvad enten der så er tale om produkt, service, organisatoriske eller policymæssige forandringer. Endelig er det vigtigt at understrege, at definitionen ifølge Sørensen og Torfing ikke indeholder en normativ vurdering af, hvorvidt en given innovation er god eller dårlig, eller om effekterne er positive eller negative (Sørensen og Torfing, 2011a: 29; 2011b: 849).

En af fordelene ved at foretage et skifte fra en eksplicit til en processuel definition er, at det åbner mulighederne for en øget responsivitet i forhold til specifikke case-analyser. Omvendt er risikoen, at et sådant innovationsbegreb i sin kontekstafhængighed mister noget af sin analytiske kraft (Pollitt, 2011; Osborne og Brown, 2011).

Selve analysemodellen er eklektisk i sin karakter og er, ifølge forfatterne, inspireret af både erhvervsøkonomisk innovationsteori, sociologisk planlægningsteori og endelig moderne teorier om netværksstyring (Sørensen og Torfing, 2011a; 2011b). Formålet med modellen er at skitsere et skelet, der kan 
hjælpe med at identificere de væsentligste elementer og disses samspil, som bør inddrages i konkrete analyser. Det er således modellens evne til at udfylde denne rolle, såvel som dens evne til at generere relevante spørgsmål, som vi vurderer den på, og som vi vil vende tilbage til i denne artikels afrunding.

Figur 1: Analytisk model til studiet af samarbejdsdrevet innovation i den offentlige sektor

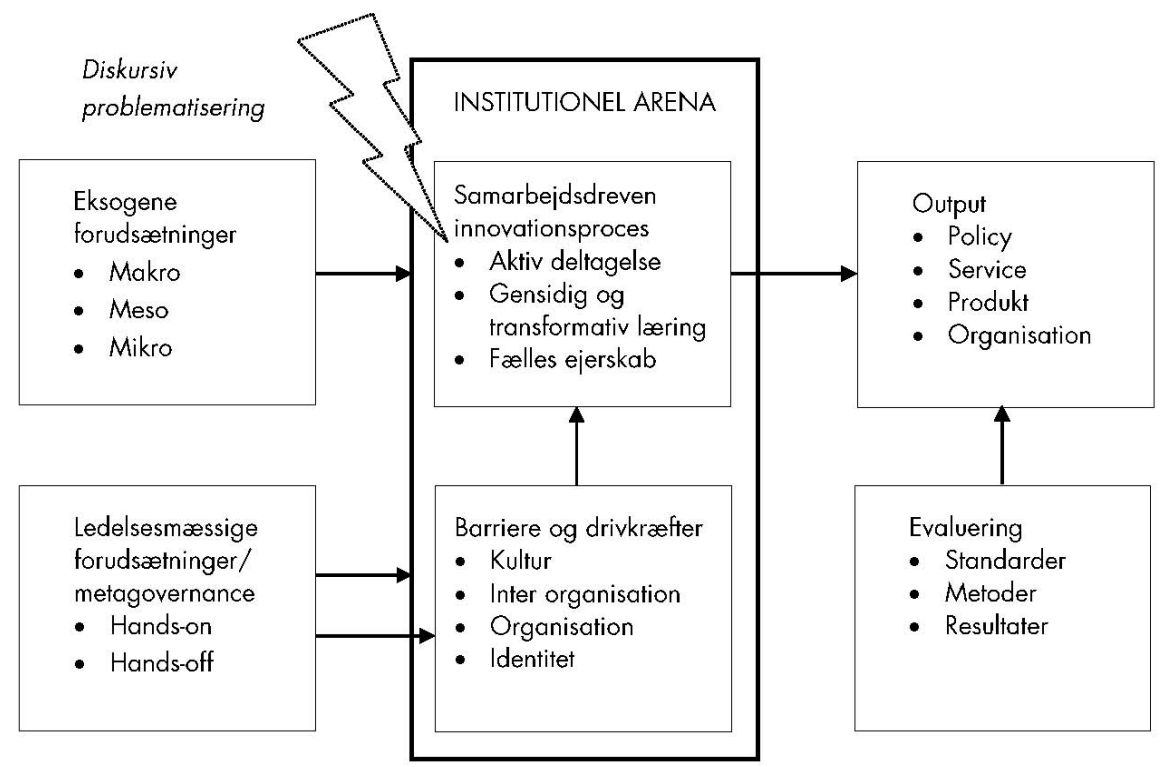

Med udgangspunkt i figur 1 tager analysemodellen afsæt i den grundantagelse, at alle innovationsprocesser er initierede. Det vil sige at der er sket en problematisering eller italesættelse på den ene eller anden måde - lynet i modellen - af et udviklingspotentiale, et behov eller en problematik, som den givne organisation finder det vigtigt at forfølge. Samtidig er det en grundantagelse at alle innovationsprocesser er indlejrede i en given institutionel arena (fremhævet med fed i figuren), som indeholder en række drivkræfter og barrierer, der enten fremmer eller hæmmer samarbejde og innovation. Denne institutionelle arena er samtidig påvirket af en række eksogene faktorer på mikro-, meso- og makroniveau, samt af de former for ledelse eller metastyring, der gør sig gældende - de to kasser til venstre i figuren. Med metastyring menes forskellige former for direkte og indirekte netværksstyring, koordination og ledelse af selvledelse (Löfgren, 2012: 15; Sørensen, 2006: 98; Jessop, 1998: 14, 42; Kooiman, 1993: 
46-47). Resultatet er en eller anden form for kvalitativ forandring, der på forskellig vis, afhængigt af normer, værdier og metoder etc., kan evalueres og vurderes - de to kasser til højre i figuren (Sørensen og Torfing, 2011b: 858). På denne vis kan modellen grundlæggende analytisk inddeles i fire faktorer, som kan siges at indvirke på den institutionelle arena, i hvilken innovationsprocessen er indlejret. Med disse analytiske faktorer menes aspekter af den samlede innovationsproces, der er centrale for at kunne forstå og forklare, hvad der er foregået. Når vi betegner disse faktorer som analytiske, er det for at understrege, at der er tale om faktorer, som i praksis ofte vil være både sammenhængende og overlappende, men hvor det af analytiske årsager kan være nødvendigt at skelne mellem dem.

1. Eksogene faktorer.

2. Ledelsesmæssige eller metastyringsfaktorer.

3. Institutionelle vilkår der enten fremmer eller hæmmer samarbejdsdrevne innovationsprocesser.

4. Procesmæssige faktorer.

Til disse faktorer kan også henregnes 5) diskursive faktorer, der er medvirkende til at skabe en forståelse eller erkendelse af behovet for innovation samt 6) evalueringen eller den efterfølgende vurdering af processen og resultaterne. Disse har vi imidlertid i al væsentlighed valgt at afgrænse os fra.

I det følgende er omdrejningspunktet en skitsering af vores analysestrategi samt koblingen mellem de analytiske faktorer og konkretiseringen af en række specifikke analyseparametre, der skal udgøre afsættet for case-analysen.

\section{Analysestrategi, metode og data}

Selvom de fire ovennævnte analytiske faktorer giver os nogle heuristiske pejlemærker for en case-analyse, er der i mindre grad tale om en færdig analyseramme egnet til konkrete empiriske studier. Vi har i vores analysestrategi valgt først at studere de fire analytiske faktorer som separate faktorer, der enten fremmer eller hæmmer innovation i den offentlige sektor, for så efterfølgende at diskutere deres indbyrdes relationer. Dette gjorde vi ved at formulere en række konkrete arbejdsspørgsmål som operationaliseringer af de fire analy tiske faktorer. Selve arbejdsspørgsmålene er vores tentative forsøg på at operationalisere en i grunden heuristiske model. Konkret er de formuleret med afsæt i en refleksivproces dels i forbindelse med det feltarbejde, der ligger til grund for vores case, dels i forbindelse med afrapporteringen af dette feltarbejde (Schultz Larsen, 2012), og sidst men ikke mindst i forbindelse med de løbende diskus- 
sioner i CLIPS-projektet af den pågældende case såvel som samarbejdsdrevet innovation i den offentlige sektor mere generelt:

\section{Eksogene faktorer}

- Hvilke traditioner er der for samarbejdsdrevne processer med borgere generelt inden for den specifikke policy-sektor? (makro)

- Er der nogle særlige legale-institutionelle vilkår for samarbejde (herunder borgerinddragelse)? (meso)

- Er der på frontmedarbejderniveau gode eller dårlige erfaringer med samarbejde (herunder borgerinddragelse), og hvilke incitamenter er der til samarbejde (mikro)?

2. Ledelse/metastyring

- På hvilken måde understøtter/modarbejder ledelse samarbejdsdrevet innovation?

- Er der tale om aktiv eller passiv styring, og er den regelbaseret eller netværksbaseret?

3. Institutionelle faktorer

- Hvilke institutionelle barrierer og drivkræfter hæmmer og fremmer innovation: institutionelle siloer, kulturer, normer, rutiner, diskurser, hierarkier og netværker?

4. Procesmæssige faktorer

- Er der tale om en mægtig-/myndiggjort deltagelse?

- Føler deltagerne medejerskab til nye ideer og løsninger?

Da formålet med denne artikel er at vurdere en analysemodel, vil disse spørgsmål primært fungere som analytiske fikspunkter, hvor vores forskningsinteresse lige så meget knytter sig til de resultater, modellen leverer, som til de empiriske fænomener i vores case, der ikke umiddelbart indfanges, og til de problemstillinger, hvor den ikke er præcis nok.

I relation til den konkrete case udspringer vores empiri fra et delprojekt under ovennævnte CLIPS-projekt, hvor vi studerede, hvordan Rigspolitiet i samarbejde med NSjP afprøvede mulighederne for borgerinddragelse i det kriminalpræventive arbejde gennem mobilteknologi - et pilotprojekt, der fik navnet TRYK Politi (NSjP, 2011a; 2011b). Metodemæssigt er der tale om anvendelse af en række forskellige data og metoder bestående af deltagerobservationer og feltdagbogsnotater (af møder og workshops mv. i regi af TRYK Politi), kvalitative interviews (seks længere interviews samt seks opfølgende samtaler) med respondenter fra forskellige niveauer og afdelinger af politiet, studier af primærdokumenter produceret af eller i relation til TRYK Politi 
(fx løbende mødereferater, projektkommissorium, projektbeskrivelser og evalueringer mv.), analyser af operations- og performancedata fra TRYK Politi samt en del rapporter og arbejdspapirer udarbejdet til CLIPS forskningsprojektet (Schultz Larsen, 2012). De indsamlede data og de anvendte metoder er behandlet kvalitativt og på samme epistemologiske og paradigmatiske niveau med udgangspunkt i en multi-method-tilgang (Teddlie og Tashakkori, 2009). For nærmere beskrivelse af vores data samt behandlingen af disse henvises til Schultz Larsen (2012).

\section{De eksogene faktorer: baggrunden for TRYK Politi}

Formålet med TRYK Politi var at afprøve mulighederne for at inddrage borgerne mere aktivt i det kriminalpræventive arbejde ved hjælp af mobilteknologi - såkaldt m-policing (Rigspolitiet, 2010c). Vores interesse i TRYK Politi var imidlertid ikke det teknologiske aspekt men derimod politiets implicitte ønske om at inddrage og samarbejde med borgerne. Når ideen om borgerinddragelse fangede an i 2010, var det hovedsagelig fordi der blev konstateret en massiv stigning i antallet af indbrud i privat beboelse i Nordsjællands politikreds i 2009. Når indbrud i privat beboelse var et centralt tema, skal dette blandt andet ses i lyset af politireformen fra 2007 og den efterfølgende kritik af blandt andet "politisvigt" (Schultz Larsen, 2012: 10-11; Balvig et al., 2011: 23-25).

I første omgang førte dette blandt andet til oprettelsen af et forsøg med et direkte telefonnummer til en særlig indbrudsenhed, hvor berørte borgere kunne ringe ind. Resultatet af dette forsøg var, til NSjP overraskelse, en stor opmærksomhed fra borgernes side. Samtidig blev NSjP opmærksomme på et projekt i Holland (Burgernet), der kombinerede mobiltelefoni og inddragelsen af borgere i det kriminalpræventive arbejde (Schultz Larsen, 2012: 20).

Med inspiration fra Burgernet formåede NSjP at vække Rigspolitiets interesse, blandt andet pga. tilkomsten af en ny rigspolitichef, der understregede behovet for en mere professionel projektstyring og for at fremme innovation inden for politiet (Rigspolitiet, 2010a). Dette førte til et fællesudkast til TRYK Politis første projektkommissorium (Rigspolitiet, 2010b). Her blev TRYK Politi udformet som et mindre pilotprojekt, der skulle operere inden for nogle snævre rammer og med begrænsede ressourcer i et samarbejde mellem Rigspolitiet og NSjP. I det første udkast var målet alene at teste mulighederne for, hvorvidt en sådan teknisk platform kunne etableres, og hvorvidt et samarbejde med borgerne ville være muligt (Rigspolitiet, 2010b). Teknisk betød dette, at pilotprojektet blev barberet ned til at være en simpel sms-baseret løsning uden den geografiske positionering, der var udgangspunktet for Burgernet. Omvendt blev der lagt stor vægt på samarbejdsrelationerne med borgerne. Det 
konkrete koncept kom på denne måde til at bestå $\mathrm{i}$, at tilmeldte borgere, når politiet har brug for deres hjælp, modtager en sms, der forklarer, hvad borgerne skal holde øje med og eventuelt melde tilbage om. Observerer borgeren efterfølgende noget, kontaktes politiet ved at besvare sms'en (Rigspolitiet, 2010b).

Baggrunden for projektet kan på denne måde betegnes som en brændende platform, der fik aktørerne - NSjP og Rigspolitiet - til for en kort periode at se bort dels fra tidligere måder og traditioner for at køre udviklings- og pilotprojekter på, dels måderne at håndtere det kriminalpræventive arbejde på. Udgangspunktet for TRYK Politi var således, at der til trods for en meget begrænset erfaring med borgerinddragelse og samarbejdsdrevet innovation blev iværksat et pilotprojekt, hvor disse elementer var omdrejningspunktet. Snarere end den institutionelle forhistorie, var det således pres og impulser udefra og en ny ledelse, der fremmede projektet i den indledende fase.

\section{Ledelse og metastyring}

I relation til det ledelsesmæssige, så er TRYK Politi et godt eksempel på en proces karakteriseret ved metastyring af et netværk af aktører. Netværket omkring TRYK politi var bredt sammensat af aktører fra en række forskellige sammenhænge og inkluderede private virksomheder, aktører fra forskellige afdelinger i Rigspolitiet herunder kommunikationsafdelingen og it- og projektafdelingen samt aktører fra NSjP's ledelse, hr-afdeling, kommunikationsafdeling, juridisk kontor, den operationelle søjle samt projekt- og udviklingsafdelingen. Endelig var en række andre eksterne parter mere eller mindre involveret i TRYK Politi.

Umiddelbart kunne indtrykket være, at projektledelsen og styregruppen gennem en forholdsvis passiv tilgang formåede at få styret et netværk af aktører i en bestemt retning med henblik på at få afprøvet et pilotprojekt med nationalt potentiale. Imidlertid bliver ledelsesdiskussionen mere tvetydig end som så. I forhold til de formål og ideer der var blevet nedfældet i projektkommissoriet, opstod der relativt hurtigt en interesseforskydning mellem Rigspolitiet og NSjP. NSjP pressede på for, at der skulle komme mere ud af projektet end blot en foranalyse, og at projektet skulle have praktisk relevans for NSjP. Hermed udfordrede NSjP de vante forretningsgange inden for politiet. At NSjP kunne gøre dette, skyldes i vidt omfang lederne i NSjP's fornemmelse for de organisatoriske mulighedsrum på det pågældende tidspunkt for at bruge Kingdons terminologi (Kingdon, 1995). Dette policy window skyldes dels organisationsforandringerne i Rigspolitiet som følge af politireformen, dels at visse dele af Rigspolitiet gerne så en kvalitativ forandring af samarbejdet mellem Rigspolitiet og de enkelte politikredse i retning af en mere horisontal relation. 
Dette står i kontrast til den traditionelle tilgang, der er mere bureaukratisk og topstyret fra Rigspolitiets side (Schultz Larsen, 2012: 26).

Enigheden omkring, at projektet skulle køre, betød således ikke, at der var enighed om, hvorledes det skulle køre, eller hvad dets endelige formål skulle være. Der var med andre ord et behov for at finde en form, hvor parterne kunne "få tandhjulene til at falde i hak", som en af deltagerne formulerede det (citeret fra Schultz Larsen, 2012: 27). I NSjP herskede der på daværende tidspunkt en helt entydig ledelsesmæssig opbakning til projektet, og samtidig var der i hele organisationen en stærk vilje til at håndtere indbrudssituationen. Omvendt var der på daværende tidspunkt en vis splittelse og handlingslammelse i Rigspolitiet, dels forårsaget af politireformen, dels af tilkomsten af en ny topledelse (Balvig et al., 2011: 18-21). Med udgangspunkt i den stærke interne enighed og vilje gik NSJP meget aktivt ind i sagen og pressede på for, at projektet ikke bare skulle være et papirprojekt men et konkret innovationsprojekt. Det betød, at NSJP, i forhold til rollefordelingen, reelt overtog projektet og ansvaret fra Rigspolitiet (Schultz Larsen, 2012: 27-29). Projektet forblev dog officielt i regi af Rigspolitiet under det nationale efterforskningscenter for indbrud (NEC) (Schultz Larsen, 2012: 26-30). Men denne forskydning gav spændinger, da det udfordrede de vante forretningsgange inden for politiet.

Der var også et andet aspekt, hvori de ledelsesmæssige faktorer spillede en væsentlig rolle. Med den entydige ledelsesmæssige opbakning og den lokale forankring i NSjP blev der skabt et konkret innovationsrum, hvor det var muligt at "tænke ud af boksen" og "lege med ideerne" om, hvorledes dette projekt kunne komme til at se ud (Rigspolitiet, 2010c). Omvendt betød overdragelsen af projektet til NSjP og den stærke opbakning også et udtalt forventningspres, hvor ideerne, der blev udviklet, meget hurtigt blev konfronteret med virkeligheden. Dette førte til, at NSjP fik udviklet et fuldt funktionsdygtigt system på kun godt og vel otte uger. Men tidspresset og en dominerende 'gør-det-selv'kultur bevirkede, at det var en meget snæver kreds, der stod for selve udviklingen af ideerne og konceptet. Samtidig førte tidspresset og gør-det-selv-kulturen også til, at borgerne i realiteten blev helt afkoblet fra udviklingsprocessen. På denne måde giver det mere mening at betegne projektet som et borgeraktiveringsprojekt end et borgerinddragelsesprojekt (Schultz Larsen, 2012: 40).

Kort sammenfattet er ledelsesproblematikken i TRYK Politi flertydig. Først og fremmest peger vores case på, hvordan ledelsen i NSjP fik mulighed for at spille på de modsætninger, der gjorde sig gældende i Rigspolitiet. Dette udnyttede ledelsen i NSjP til at tage ejerskab over et projekt på en ny måde, der ikke tidligere er set inden for politiet. Samtidig udgjorde den interne mobilisering 
i NSjP, tidspresset og gør-det-selv-kulturen, at der blev tale om en ganske fast form for metastyring.

\section{Institutionelle faktorer: barrierer og drivkræfter}

Resultatet af rollefordelingsprocessen og den entydige ledelsesmæssige opbakning fra NSjPs side betød, at der blev etableret et fælles sprog eller med andre ord en række implicitte spilleregler for, hvorledes arbejdet med TRYK Politi skulle forløbe. Med hensyn til mulige institutionelle barrierer og drivkræfter er der flere relevante resultater, der fremkommer med vores case.

Af drivkræfter kan for det første fremhæves skabelsen af det - i forhold til politiet - bredt sammensatte og unikke netværk omkring udviklingen af TRYK Politi (Schultz Larsen 2012: 53). Dette var en vigtig faktor, hvor en ny og mere "åben" samarbejdskultur inden for netværket medvirkede til at drive processen. Det samme kan siges om etableringen af ovenfornævnte innovationsrum. En tredje faktor, der måske lidt paradoksalt har medvirket til at drive TRYK Politi frem, har været manglen på konkrete specifikationer og succeskriterier for selve projektet. Det første projektkommissorium (Rigspolitiet, 2010b) indeholder kun få konkrete tekniske og administrative anvisninger og kan i realiteten bedre forstås som en hensigtserklæring for et fremtidigt kriminalpræventivt borgerinddragelsessystem. Samtidig blev de sædvanlige procedurer for projektstyring også omgået, da TRYK Politi blev overdraget fra Rigspolitiet til NSjP. En projektstyring der normalt forudsætter udarbejdelsen af en business-case, som er opdelt i en række faste faser, og som munder ud en cost-benefit-analyse (Schultz Larsen, 2012: 59). Men i modsætning til en sådan projektstyring blev det skabte innovationsrum koblet med en innovationsproces uden klare kriterier og specifikke mål.

Ud over drivkræfterne har der været en række institutionelle barrierer på spil i udviklingen af TRYK Politi. Her er gør-det-selv-kulturen, som vi har omtalt tidligere, formentlig den væsentligste. Denne gjorde det svært at håndtere ideen om, at eksterne aktører, herunder borgere, skulle deltage i processen. Så selvom der på mange måder kan tales om et vellykket projekt, lå nøglen til den umiddelbare succes ikke i borgerinvolvering, men tværtimod i en snæver udvalgt og afgrænset gruppe af aktører. Det betyder, at projektet allerede i sin udviklingsfase gik glip af de potentielle ressourcer, der ligger i at inddrage en lang række forskellige aktører.

Hermed har der været både institutionelle barrierer og drivkræfter på spil i innovationsprocessen omkring TRYK Politi. Det kan dog diskuteres, hvad der i realiteten definerer en barriere og en drivkraft. Gennemgangen af de forskellige dele af projektet tyder således på, at forskellige elementer er barrierer 
på nogle tidspunkter og drivkræfter på andre tidspunkter. Fx har en del af de faktorer, som vi har benævnt drivkræfter, bestået i en eksklusion af forskellige grupper fra udviklingsfasen - særligt borgerne. Gør-det-selv-kulturen er et godt eksempel på denne dobbelthed; som en barriere der ekskluderer en række potentielle ressourcer og løsningsmuligheder, men også en drivkraft der rent faktisk gjorde det muligt at udvikle et fuldt funktionsdygtigt projekt på kun otte uger.

\section{Procesmæssige faktorer}

Der var flere faktorer på spil i og omkring selve innovationsprocessen, men her vil vi kun kort forholde os til to. Først og fremmest var det interessant at se, hvorledes hele forløbet i høj grad har været en læringsproces for de aktivt involverede aktører. Omvendt fik særligt de eksterne aktørers (borgerne og de medarbejdere der skulle anvende systemet) læring karakter af passiv modtagelse af information snarere end en fælles proces præget af medejerskab. Denne diskussion omkring medejerskab spiller også en rolle i en anden af de faktorer, der har kendetegnet processen omkring TRYK Politi.

Den anden faktor, som træder klart frem, er den markante udvikling af projektet, der skete fra de første ideer i sommeren 2010, som omhandlede nedbringelse af indbrud i privat beboelse (Rigspolitiet, 2010b), til det projekt, der blev endeligt evalueret i august 2011, som fokuserede på bløde parametre som "usynlig tryghed", citizenship og awareness (NSjP, 2011b). Dette skifte i TRYK Politi var ikke direkte intenderet fra starten, omvendt var der heller ikke tale om et ubevidst skred. Interessant i denne sammenhæng var imidlertid, at der internt i politiet var forskellige opfattelser af denne udvikling. På den ene side var der dem der mente, at udviklingen burde anskues som første skridt i retning af en ny måde for politiet at håndtere innovation på og mere generelt politiets måde at opfatte borgerne på. Som en af deltagerne i projektet udtrykker det: "Projektet har undergået et paradigmeskifte. Forstået på den måde, at projektet i højere grad kan ses som en spydspids for 'partnerskabet med borgerne', snarere end en succes på den operationelle anvendelse" (Referat fra styregruppemøde, 4. maj 2011).

Omvendt blev dette skifte også kritiseret, og mest markant kom dette til udtryk under en evaluerings-workshop i januar 2011, hvor en af deltagerne betegnede projektets "paradigmeskift" som et udtryk for dårlig projektstyring og mission сrеep (Feltnoter, 26. januar 2011). Denne drejning fra "produktinnovation" mod "symbolsk innovation" var der ingen af deltagerne i projektet, der var uenige i. Spørgsmålet var imidlertid, hvordan de forskellige aktører anskuede denne udvikling. Med dette modsætningsforhold blev det tydeligt, 
at det, der var på spil med TRYK Politi, ikke bare var et mindre innovationsprojekt men også et tovtrækkeri om, hvilke forskellige rationaler der skal være gældende inden for politiet i forhold til politiets selvopfattelse og anskuelse af egen rolle. Det skal naturligvis ikke forstås således, at et, i sammenligning med politiet in toto, mikroskopisk innovationsprojekt til $500.000 \mathrm{kr}$. og to årsværk er afgørende for udviklingen af fremtidens politi. Men derimod at innovationsprojektet og processen omkring det kom til at reflektere en række af de mere dybtliggende forandringsprocesser i organisationen og de forskellige og til tider modstridende rationaler, der gjorde sig gældende i denne sammenhæng.

Skal vi sammenfatte dette kort, synes implikationen at være, at TRYK Politi i en bredere kontekst på en og samme tid skal forstås både som et konkret innovationsprojekt og som et organisationsstrategisk tiltag. Dette understreger i realiteten en af de grundlæggende faktorer, der adskiller innovation i hhv. den private og den offentlige sektor. At der helt grundlæggende er tale om politiske processer i den offentlige sektor, hvor forskellige former for magtspil mellem forskellige interesser og grupper er centrale for at kunne forstå processerne (Hartley, 2005; Røste og Miles, 2005; Sundbo, 1997). Her bliver spørgsmålet, om ikke alle innovationsprocesser i den offentlige sektor bør analyseres som "dobbeltprocesser", der dels handler om "konkrete innovationer", dels handler om "politiske processer" og om, hvorledes forskellige involverede grupper eller aktører anskuer de givne institutionelle rammer?

Relevansen af ovenstående forståelse synes også understreget i forhold til at kunne forklare det videre forløb i processen omkring TRYK Politi. Det endelige resultat blev således, at TRYK Politi henover sommeren 2011 i realiteten blev kørt ud på et sidespor. Vurderingen og evalueringen af projektet fra Rigspolitiets side endte med at anskue forløbet omkring TRYK Politi som et udtryk for en innovationsproces, der var kørt skævt i forhold til målsætningerne. Indstillingen blev på denne baggrund, at der ikke var tale om en innovation, som var egnet til at nationalisere pga. manglende performance. Dette til trods for at projektet opnåede sammenlignelige resultater målt på en række objektive variable i forhold til det hollandske projekt, der inspirerede til TRYK Politi (Schultz Larsen, 2012: 44-45). Mere overordnet understreger indstillingen imidlertid, hvorledes forskellige aktører og deres forestillinger, normer og værdier har indflydelse på de konkrete innovationsprocesser og på betingelserne for, hvorvidt en given proces efterfølgende forstås som en succes eller ej. I forhold til de forudsætninger der er med til at udforme den givne institutionelle arena, er det også relevant at understrege det helt grundlæggende forhold mellem Rigspolitiet og NSjP. Hvor den indledende proces med hensyn til rollefordelingen, hvor NSjP tog teten, udgjorde en konkret drivkræft 
for innovation, endte den i den afsluttende fase med at blive den væsentligste barriere. De aktører i Rigspolitiet, der skulle evaluere og vurdere TRYK Politi, kunne ikke længere identificere sig med projektet, fordi det havde udviklet sig til at repræsentere nogle grundlæggende værdier, normer og en problemopfattelse, der var helt forskellig fra deres.

\section{Opsamling og diskussion}

Vores brug af Sørensens og Torfings analysemodel illustrerer på mange måder kvaliteterne og anvendeligheden af modellen med hensyn til at analysere samarbejdsdrevne innovationsprocesser i den offentlige sektor. De analytiske faktorer, modellen opstiller, giver både mening og er anvendelige som operationelle pejlemærker for empiriske studier. Således vurderer vi på baggrund af vores case-analyse, at modellen både er i stand til at generere relevante hypoteser, producere relevante undersøgelsesspørgsmål, og at den bidrager til relevante og forklaringsbærende analyser. Imidlertid giver mødet mellem modellen og den empiriske case anledning til en række overvejelser vedrørende udfordringerne - særligt i forhold til fremtidig teoriudvikling.

Det første punkt, vi gerne vil henlede opmærksomheden på, relaterer sig til selve definitionen af innovationsbegrebet og det processuelle aspekt ved modellen. Hvor dette på den ene side viste sig at gøre modellen anvendelig og meningsfuld i analysen af innovationsprocesser, opstår der på den anden side en udfordring i forhold til at anvende modellen til at vurdere, hvornår en innovationsproces i realiteten skaber innovation. Hvis vi kort vender tilbage til de fem implikationer af innovationsdefinitionen, som Sørensen og Torfing fremhæver, og relaterer dem til vores case, illustreres udfordringen. Spørgsmålet er, hvorvidt TRYK Politi kan betegnes som en innovation. Selvom ideen til TRYK Politi er inspireret af det hollandske Burgernet, er der ingen tvivl om, at selve projektet i høj grad er blevet tilpasset og oversat til den nordsjællandske kontekst. Samtidig var der også helt klart tale om et eksplicit forsøg på bevidst at skabe forandringer. Ideen blev også omsat og implementeret i organisationen, hvilket 60 gennemførte operationer over en seks måneders periode vidner om. Men på spørgsmålet om hvorvidt TRYK Politi formåede at skabe en kvalitativ forandring, synes modellen at komme til kort. Nøgternt set havde projektet en operativ succesrate på 9 pct., hvilket er på linje med det større og mere avancerede Burgernet (Schultz Larsen, 2012: 45). På den anden side blev TRYK Politi som nævnt ikke nationaliseret. Det stiller spørgsmålet om, hvad der egentlig skal forstås med begrebet "en kvalitativ forandring"? Samtidig bliver det åbenlyst, at definitionen afhænger af, hvilke aktørperspektiver der privilegeres. Heraf følger endvidere, at det bliver vanskeligt at håndtere den sidste implikation 
ved definitionen, der stipulerede, at der ikke er tale om en normativ definition. Det skal imidlertid retfærdigvis nævnes, at forfatterne selv gør opmærksom på, at vurderingen af en innovation "afhænger ... af øjnene der ser" (Sørensen og Torfing, 2011a: 20). Omvendt synes forfatternes opfordring til at foretage en samlet vurdering, der inddrager alle berørte parters opfattelser af resultaterne, ikke at løse dette problem (Sørensen og Torfing, 2011a: 20). Videre gør samme definitoriske usikkerhed sig også gældende i forhold til, hvornår noget fremmer eller hæmmer innovation. Som analysen af vores case viste, udgjorde forskellige kulturelle, organisatoriske og ledelsesmæssige faktorer både barrierer og drivkræfter for innovation på forskellige tidspunkter i processen. Det vil sige, at en given faktor kan udgøre både en barriere og en drivkræft i den samme innovationsproces.

En anden udfordring i forhold til det begrebsdefinitoriske er, hvorvidt man ville nå de samme resultater, hvis man undersøgte innovationsprocesser i den private sektor. Hverken begrebsdefinitionen eller modellen fremdrager således nogle særlige implikationer vedrørende det faktum, at der alene ses på innovationer i den offentlige sektor. Denne udfordring skal også ses i relation til den ovenstående diskussion om nødvendigheden af at forstå de specifikke politiske processer, som innovation i den offentlige sektor er indlejret i. Det er således et åbent spørgsmål, om modellen kan siges at indfange dette perspektiv som en del af de eksogene forudsætninger, eller hvorvidt det skal analyseres i relation til de barrierer og drivkræfter, der gør sig gældende i den enkelte institutionelle arena.

Sidst men ikke mindst synes der at ligge et større teoretisk udviklingsarbejde forude $\mathrm{i}$ forhold til at udfolde innovationsdefinitionens relation til flere af de indeholdte begreber $\mathrm{fx}$ i forhold til læringsteori og modellens begreb om fællesejerskab. Dette ændrer imidlertid ikke ved det forhold, at der er tale om en både interessant og relevant model, som giver mening og er anvendelig i empiriske studier.

\section{Litteratur}

Balvig, Flemming, Lars Holmberg og Maria Pi Højlund Nielsen (2011). Verdens bedste politi - Politireformen i Danmark 2007-2011. København: Jurist og Økonomforbundets forlag.

Bason, Christian (2007). Velferdsinnovation - Ledelse af nytenkning i den offentlige sektor. København: Børsens Forlag.

Bhatti, Yosef, Asmut Leth Olsen og Lene Holm Pedersen (2011). Administrative Professionals and the Diffusion of Innovations: The Case of Citizen Service Centres. Public Administration 89 (2): 577-594. 
Bommert, Ben (2010). Collaborative Innovation in the Public Sector. International Public Management Review 11 (1): 15-33.

Fuglsang, Lars og John S. Pedersen (2011). How Common is Public Sector Innovation and How Similar Is It to Private Sector Innovation?, pp. 44-60 i Victor Bekkers, Jurian Edelenbos og Bram Steijn (red.), Innovation in the Public Sector: Linking Capacity and Leadership. Basingstoke: Palgrave Macmillan.

Hartley, Jean (2005). Innovation in Governance and Public Services: Past and Present. Public Money and Management 25 (1): 27-34.

Healey, Patsy (2007). Urban Complexity and Spatial Strategies: Towards a Relational Planning for Our Time. London: Routledge.

Jensen, Kirsten Engholm, Jens Peter Jensen, Annemette Digmann og Henrik W. Bendix (2008). Principper for offentlig innovation - fra best practice til next practice. København: Børsens Forlag.

Jessop, Bob (1998). The Rise of Governance and the Risk of Failure: The Case of Economic Development. Oxford: Basil Blackwell.

Kingdon, John W. (1995) Agendas, Alternatives and Public Policies, 2. udgave. Cambridge: Pearson Publishing.

Kooiman, J. (1993) Modern Governance. New Government-Society Interactions. London: Sage.

Kristensen, Catharina J. og Søren Voxted (red.) (2011). Innovation og entreprenørskab. København: Hans Reitzels Forlag.

Löfgren, Karl (2012). Netværksstyring af e-government. Politik 15 (3): 14-22.

Mulgan, Geoff og David Albury (2003). Innovation in the Public Sector. Prime Minister's Strategy Unit. London: Government of the United Kingdom.

NSjP (2011a). Indstilling vedrørende TRYK Politi. Helsingør: Nordsjællands Politi og Rigspolitiet.

NSjP (2011b). Projekt SMS - TRYK Politi - evaluering af efterforskningsdelen i SMS systemet. Helsingør: Nordsjællands Politi.

Osborne, Stephen og Louise Brown (2011). Innovation, Public Policy and Public Services Delivery in the UK: The Word that Would be King? Public Administration 89 (4): 1335-1350.

Pollitt, Christopher (2011). Innovations in the Public Sector - An Introductory Overview, pp. 25-43 i Victor Bekkers, Jurian Edelenbos og Bram Steijn (red.). Innovation in the Public Sector: Linking Capacity and Leadership. Basingstoke: Palgrave Macmillan.

Rigspolitiet (2010a). Politiets og anklagemyndighedens strategi for 2011-2015. København: Rigspolitiet.

Rigspolitiet (2010b). Projektkommissorium: Borgervarsling/Borgeralert. København: Rigspolitiet. 
Rigspolitiet (2010c). Projektbeskrivelse: Borgervarsling/Borgeralert. København: Rigspolitiet.

Røste, Rannveig og Jan Miles (2005). Differences in Public and Private Sector Innovation. Oslo: Publin Report D. 9.

Schultz Larsen, Troels (2012). Tryk Politi - case beskrivelse og diskussion af projektets barrierer og drivkræfter for samarbejdsdrevet innovation i den offentlige sektor. CLIPS working paper $n r$. 8. Roskilde: Roskilde Universitet.

Sundbo, Jon (1997). Management of Innovation in Services. Service Industries Journal 17 (3): 432-455.

Sørensen, Eva (2006). Metagovernance: The Changing Role of Politicians in Processes of Democratic Governance. The American Review of Public Administration 36 (1): 98-114

Sørensen, Eva og Jacob Torfing (2011a). Samarbejdsdrevet innovation i den offentlige sektor, pp. 19-40 i Eva Sørensen og Jacob Torfing (red.), Samarbejdsdrevet innovation i den offentlige sektor. København: Jurist og Økonomforbundets Forlag.

Sørensen, Eva og Jacob Torfing (2011b). Enhancing Collaborative Innovation in the Public Sector. Administration \& Society 43 (8): 842-868.

Teddlie, Charles og Abbas Tashakkori (2009). Foundations of Mixed Methods Research. Thousand Oaks: Sage Publications.

Vigoda-Gadot, Eran, Aviv Shoham, Nitza Schwabsky og Ayalla Ruvio (2008). Public Sector Innovation for Europe: A Multinational Eight-Country Exploration of Citizens' Perspectives. Public Administration 86 (2): 307-329. 